\title{
FROM CONVERSATION TO PROVERBS: ESTONIAN IKKA- AND IKS-CONSTRUCTIONS
}

\author{
Karl Pajusalu, Renate Pajusalu
}

\begin{abstract}
The article provides an overview of the use of the Estonian particle $i k k a$ 'sure, still' in spoken Estonian and makes an attempt to explain why this particle is so common in proverbs and South Estonian folk songs. Etymologically, $i k k a$ is associated with a temporal meaning and stems from the word iga 'time, lifetime, full time'. In contemporary Estonian ikka refers to the typicality and recurrence of an action, but it also points to an interruption in the continuity of an action after which the previous situation is restored. As such it marks (re-)validity in fixed expressions and folklore; however, it could also serve as a means of showing continuity of narrative discourse. The article focuses on the occurrence of $i k k a$ in contemporary spoken language and proverbs (both in the database and in the contemporary media language) and on a special usage of the expletive iks / $\tilde{k} s$ in Setu/Seto South Estonian folk songs. In folklore, as well in contemporary informal speech, the use of $i k k a$ is motivated both by lexical meaning on the syntactic level and the general structure of discourse.
\end{abstract}

Key words: conversation, Estonian, narrative, proverbs, semantics, temporal constructions

\section{INTRODUCTION}

The emphatic particle $i k k a$ or $i k s$ 'sure, yes, again, still', etc. is among the most frequent words in Estonian. In Estonian dialects $i k k a$ together with its phonetic variants is among the ten most frequent words - ikke in the north-eastern dialect occupies the 6th place, and its South Estonian equivalent iks occupies the 10th place in the Võru South Estonian (Lindström et al. 2001).

The most important meanings of $i k k a$ are 'always' and 'contrary to what was thought in the meanwhile'. These two meanings, which seem to be opposites at first glance, can nevertheless be regarded as a whole if one regards the meaning 'always' as continuity of a situation. The continuity is revealed both in the meaning and in the tendency of $i k k a$ to occur repeatedly in informal conversations and folk songs by forming $i k k a$ chains, which express iconic continuity. Depending on its specific meaning, $i k k a$ or $i k s$ also occur in a number of Estonian proverbs. In proverbs $i k k a$ emphasises typicality of the statement and shows that the content of the utterance is generally valid. 
An exciting feature of $i k k a-i k s$ in spontaneous language and folk poetry is its grammaticalisation and even morphologisation - as a clitic $i k k a$ can become the structural nucleus of certain morphosyntactic constructions. For example, in Setu South Estonian folk songs $i k s \sim \tilde{o} k s$ is known as the most common and typical enclitic, which appears on the foot boundaries of compounds.

The article will at first provide a semantic description of the particles $i k k a$ and $i k s$ and thereafter focus on their function in proverbs. We attempt to present not only the usage regularities of a single word but also show the interrelations between different spheres of language use through them.

The discussion, on meanings of $i k k a$ in Standard Estonian, is based on the corpora of written and spoken Estonian at the University of Tartu; the use of the South-Estonian iks in dialect narratives and dialogues is described on the basis of the corpus of Estonian dialects. The analysis of proverbs is based on the electronic database of proverbs at the Estonian Literary Museum.

\section{IKS AND IKKA IN ESTONIAN - A GENERAL SEMANTIC DESCRIPTION}

Etymologically, $i k k a$ is derived from the noun *ikä 'time, lifetime, full time'. The same Finno-Ugric word stem gave rise to the Sami jâkke and Hungarian $e ́ v$, which both denote a year (cf. Estonian aasta 'year'< *ajastaeg, i.e. 'full time'). Julius Mägiste (EEW: 498) claimed that $i k k a$ proceeds from the illative form *ikähen, where the shortening of unstressed non-initial syllables and secondary gemination resulted in the corresponding adverb form (cf. the phonetic form of the Estonian tuppa, which was derived from the illative form *tupahen of *tupa 'room'). In the old written language and in South-Estonian dialects the corresponding form ends in -s, as in ikkas, ikas, ikis, the South-Estonian iks and its back-vowel equivalent õks are related forms. Mägiste linked $-s$ with the translative ending (in South Estonian $-k s>-s$ ); however, it is more likely that it could be linked to the possessive suffix of the third person *(n)sa; thus, ikka would be the Estonian equivalent to the Finnish $i k \ddot{a} \ddot{a} n$, and $i k s$ would correspond to the Finnish ikäänsä.

It seems that ikka was at first used as a temporal adverb in the meaning 'always', i.e. anytime. The same meaning is also known in other Finnic languages, for example, Ingrian ikkää 'always' (SSA 1: 223).

According to the Explanatory Dictionary of Estonian (EKSS 1: 582-583), $i k k a$ is an adverb with five main meanings: 
1. all the time, always, including in the fixed expressions $i k k a$ ja alati 'again and again', ikka ja jälle 'again and again':

Ikka kordus sama lugu. 'The same story happened again and again.'

2. still:

Poiss on ikka alles haige. 'The boy is still ill.'

3. continuously, usually in combination with the comparative:

Tee läheb ikka kitsamaks. 'The road is getting narrower and narrower.'

4. concessively, nevertheless with emphasis:

Kuhu tal ikka minna on. 'In fact, there is no place where he could go.'

5. sure with affirmation:

Lähed jalgsi? - Jalgsi ikka. 'Are you going to walk? - Sure.'

The description of the semantics of the word could be summarised as follows: $i k k a$ means 'always' or 'permanently, lastingly'; in addition, it has particle-like uses that are associated with emphasis and affirmation.

The Estonian academic grammar (Erelt et al. 1993: 101) lists ikka among connective extensions; it has either an adversative or a concessive-adversative meaning. The uses of $i k k a$ can be divided into two large groups: as an adverbial of time in the meaning 'always, permanently' and as a particle (or a particlelike adverb) '(despite everything) yes'.

Both the Explanatory Dictionary and the Estonian grammar reflect, first and foremost, written language. However, the same semantic groups can be found in spoken informal language. There are some situations where $i k k a$ in the meaning 'always' or 'permanently' occurs in sentences that provide background information of the narrative to the effect the way it always, or usually is. For instance, see example (1), where a narrative about specific events includes a generic statement about trains in general nagu ikka on, et tahad...'the way it is that you want to':

(1)

jah järgmisse vagunisse minema nigu ikka on et tahad restorani minna sis pead mitmest läbi käima. 'yes, to go to the next carriage that's the way it is that if you wish to go to the dining car, then you have to go through several of them.'

Leelo Keevallik (2009: 45-46) has studied the functioning of the particle $i k k a$ as an answer to yes-no-questions in spoken Estonian and found that $i k k a$ conveys an affirmative answer and, at the same time, some kind of problem with the question itself, mainly something like 'you shouldn't ask such an obvious 
thing'. This finding fits with previously described fifth meaning of $i k k a$ in the Explanatory Dictionary of Estonian. According to our data, in spoken informal communication $i k k a$ is mostly associated with those contexts where a previous claim or presumed claim or situation requires reaffirmation because of some counterclaim. This coincides with Keevallik's result concerning $i k k a$ as a nonpreferred affirmative answer (2009: 46). In example (2), A asks a somewhat weird question whether Americans wear socks. B replies probably in jest that they don't. Then a number of participants affirm that 'Americans do wear socks'.

(2)

A: [jah, (.) aga huvitav: kas nad'sukke kannavad=võ. (.) näe.

B: @ 'Amerikas 'sokke ei 'kanta. @

A: ei 'kanta=võ. (.) a mis neil 'on sis=õ. (.) [(-) (...) ikka sokid.]

B: ['on='on, on=on, jah, ikka] 'valged=ikka need jah. (.) ee noh: mis.

E: minu=arust 'armastavad 'ikka sokke [(kanda).]

B: $[\boldsymbol{i k k a}]=\boldsymbol{i} \boldsymbol{k} \boldsymbol{k} \boldsymbol{a}$. noh botaste all on ['ikka] jah.

$\mathrm{E}:[\mathrm{mhmh}]$

A: yes, but I wonder whether they wear socks

$\mathrm{B}$ : in America they do not wear socks.

A: I see, or what do they wear then, in fact, socks.

B: sure, sure, yes, in fact, white ones they do, well, what.

$\mathrm{E}$ : in my opinion, they do like to wear socks.

B: sure, sure, well, under trainers they wear, sure, yes.

E: uh huh.

In some contexts $i k k a$ shows that the speaker thinks that some conflict has emerged by comparison with what he/she had thought earlier. In example (3), A asks how much the bill is because he/she fears it to be a much larger sum than it actually is. He/she explains it by ma kartsin ikka et tuleb 78 krooni ' $\mathrm{I}$ was, in fact, afraid that it might total 78 kroons'.

(3)

A: noh no: oli=siis nii 'suur arve $=v \tilde{o}$.

M: nii 'suur arve=võe.

A: no mis see 'oli siis [ütle.]

M: [\{-\}] kakskend=üks kroo[ni.]

A: [o:h?] $m a=k a=k a=k a r t s i n$ ikka et tuleb

$\{-\}:\{--\}$

A: seitsend=`kaheksa krooni. (.) nigu 'eelmine nädal. (3.0) 
A: well, was the bill that big then or.

M: such a huge bill, or.

A: well, how much was it then, tell me.

M: twenty-one kroons.

A: I see, in fact, I was afraid that it might total

A: seventy-eight kroons, as for the previous week.

In questions $i k k a$ may also occur as doubt, again by highlighting some earlier conflicting point of view. In example (4), A wonders by asking aga lasid siis ikka pildistada? 'did they really give permission to be photographed' that B had managed to photograph some well-known people. Soon he explains his view by inserting $i k k a$ in the conversation muidu ei lasta ligidalegi 'usually they even don't allow you to get close to them'. Thus, in examples (3) and (4) ikka occurs in contexts where an earlier claim of the speaker contrasts with another claim.

(4)

A: [aga lasid siis ikka 'pildistada.] muidu öö noh ei lasta: ligidalegi. e 'antagi sulle [ültse 'võimalust.]

B: ((näitab fotole)) [ei tänava=päl] näed sõidab 'mööda, nemad on jah siin 'tänava $=$ peal $(\mathbf{i k k a})=$.

$\mathrm{A}:=a h$ tänava pääl?

B: jajah. jah.

A: but they then allowed you to take pictures, well, usually they don't, you even cannot get close to them.

B: (pointing at a photo) on the street, you can see him driving by, well, they are yes here on the street.

A: on the street?

B: yes, yes.

In addition, in informal conversations $i k k a$ may have the meaning of emotional intensification. In example (5), people have just discussed how simple it is in Germany to call abroad. The conversation dates from the time when it was not that easy in Estonia as yet, and A expresses wonder by jõle vägev ikka 'that's cool, indeed', followed by K's vinge on kohe tead ikka 'that's cool, indeed'.

(5)

A: $e i=n o=k u=s a$ 'Saksamaale elistasid. (1.5)

$\mathrm{K}$ : ei=pea ei='pea ootama [numbrit. (.) $\mathrm{mkmm}$ ]

$\mathrm{M}:$ [ei=no=ma=üt-] Reenile täna 'ütles seal=et

A: ’jõlep vägev ikka. (.) 
$\mathrm{K}$ : ku=tead=täitsa 'vinge on kohe tead ikka ['tunduvalt, tead 'teine kvaliteet on $\mathbf{i k k a}]$ täiesti. $=$

A: [ei=no ikka (...) 'parem on olla.]

A: no, well, when you made a phone call to Germany.

$\mathrm{K}$ : no, you don't have to wait for the number.

M: no, well I, told Reen today there that

A: that's cool, indeed.

K. you know, that's cool indeed, the quality is totally different, you know.

A: no, well, it's better to be.'

The fact that ikka means 'always' and that it also occurs in the context of conflicting opinions is far from accidental. One can depict the meaning 'always', which is historically clearly primary, as a chain of situations (see Fig. 1), where the same situation is recurrent.

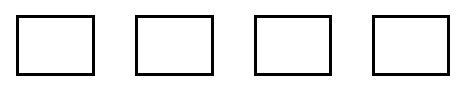

Figure 1.

On the other hand, once doubt or a counterclaim emerges in the chain, which is refuted as in example (2) with regard to whether Americans wear socks, the full picture is depicted in Figure 2, where the dotted frame denotes an opposite situation. The grammaticalisation lexicon by Bernt Heine and Tania Kuteva (2002: 259-260) includes the development chain RETURN > ITERATIVE, which can be found in several languages. $i k k a$ seems to reveal an opposite semantic chain ITERATIVE $>$ RETURN.

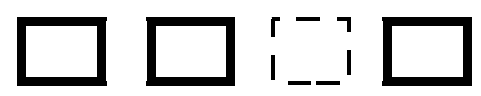

Figure 2.

As a further development of this situation, ikka can occur in contexts with only two competing opinions. In example (3), the competing opinions are that the bill is large and actually it was not that large, and in example (4), the fact that celebrities do not give permission to be photographed yet in a real situation it was still possible. As Figure 3 shows, in those situations only part of the chain of the situations is prominent (cf. Fig. 2). Here $i k k a$ carries the meaning 'yes, although in the meantime some doubt has arisen'. 


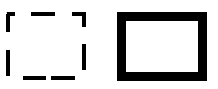

Figure 3.

In some contexts the affirmation that dispels the doubt may become an especially strong affirmation, as in the example Tulen ikka 'in fact, I'll come' illustrating sense 5 in the Explanatory Dictionary.

The second development of the chain of situations in Figure 1 is in the direction where iteration gives rise to an intensive meaning (see Fig. 4). This development is suitable for the purpose of explaining the intensification of an emotion, as showed in example (5).

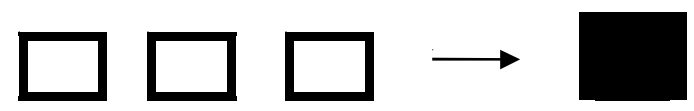

Figure 4.

This is how a grammaticalisation chain comes into being where the temporal meaning 'always' has changed into 'yes' in the semantic chain:

$\begin{aligned} \text { (full) time } & >\text { sure (despite of doubt) } \\ & >\text { always }\end{aligned}$

Our spoken language data also clearly shows that $i k k a$ tends to form chains. In example (2) ikka occurs seven times in the turns of two different speakers; in example (5) it occurs four times. Thus, the meaning of 'always, as before' of $i k k a$ is often supported by iconic continuity in informal conversations, which is similar to folk songs.

The same chain of semantic change can also be observed in South Estonian dialects where the $i k s$ may have finally become cliticised together with the emergence of a back-vowel variant, e.g. tulõ-ôks 'do come', anna-(a)ks 'do give'.

\section{IKKA IN ESTONIAN PROVERBS}

In the electronic database of proverbs at the Estonian Literary Museum, ikka can be found in various proverbs with different shades of meaning.

(a) In proverbs $i k k a \sim i k e \sim i k i \sim i k s$ usually marks typicality of the situation, that is, it adds the meaning 'always' to the utterance: 
(6) Hüvvel ike üks viga. 'Always a good thing is accompanied by a bad thing.'

(7) Armal iks au häitses. 'Always one's darling is held in great honour.'

(b) Likewise, the particle has a similar function in proverbs that refer to universality of a feature:

(8) Veri iki veri, vesi vesi. 'Blood is always blood, water is water.'

(9) Suure iks suurtega, väikese väikestega. 'Big ones keep the company of big ones, small ones associate with small ones.'

The stability of such a feature can be expressed rather productively by means of the construction ' $\mathrm{X}$ is $i k k a \mathrm{X}$ '. Here $i k k a$ denotes stability, generality, but its shade of contrast also signals that $\mathrm{X}$ is used pragmatically in two different ways: by reference to a specific referent at the beginning of the construction (such as laps 'child' in the example (10) or sõda 'war' in the example (11)) and non-referentially by referring to typical properties of the class of referents (same examples (10) and (11) in a generic context) ${ }^{1}$.

(10) Laps on ikka laps. 'A child will always be a child.'

(11) Sõda on ikka sõda 'War will always be war.'

(c) In addition to the meaning 'always', one can also observe an affirmative shade of meaning:

(12) Naesele iks nõo piät, mis sa mehele tiit. 'You can indeed give some advice to a woman, but what can you do in the case of a man.'

(13) Maias iks mao palutas. 'A sweet tooth will indeed burn his stomach.'

(d) The previous meanings are associated with a more general emphatic meaning:

(14) Ema nisa iks latse suun. 'Mother's nipple is, as a rule, in the child's mouth.'

(15) Sulasel iki suur kõht. 'A farm hand has, as a rule, a big belly.'

The previous examples show that in proverbs $i k k a \sim i k s$ commonly occurs in place of the present form of the verb olema 'be' and that a verb is formally absent from these predicative clauses, which is uncommon for Estonian (unlike Russian, for example) and is possible in figurative speech together with syntactic parallelism, e.g. Mis kallis, see ikka kaunis 'the thing that is expen- 
sive is beautiful' (Erelt et al. 1993: 55). In proverbs $i k k a$ seems to be sufficient to replace the verb olema even when there is no syntactic parallelism.

Proverbs are by their nature texts without context; however, when one thinks how and in what kind of situations a proverb is typically used, it appears that in most cases a specific occasion represents a general situation (cf. Krikmann 1997: 22, 38). It could well be that all the proverbs including the particle $i k k a$ could also occur without it. ikka adds to the meaning of the proverb the affirmation that once again everything has turned out as usual.

Occurrence of $i k k a$ in modern uses of proverbs calls for a comprehensive study. However, preliminary observations by means of the Google search engine $^{2}$ show that $i k k a$ is usually added to common affirmative proverbs that are well integrated into the conclusive mechanism of the rest of the text. For example, the proverb Veri on ( $i k k a$ ) paksem kui vesi 'blood is thicker than water' is highly common in newspaper language, and it occurs both with and without ikka.

Examples (16-18) show a few uses of this proverb in newspapers and chat rooms. What is shared by all of them is that the proverb states the situation ((16) - a biological child is dearer than a foster child; (17) - investors of the same nationality stick together; (18) - people belonging to the same nationality understand each other better even when they do not share the same political views), which is not expressly stated but is implicitly presented to the reader. In all the cases the verb olema 'be' is part of the proverb, and the proverb is integrated into the same complex sentence with the non-proverb component.

[Jututoas: üks vestleja on kurtnud, et oma lapse ja kasulapse koos kasvatamine on raske.

Vastusteksti algus:]

Pü̈̈ad olla erapooletu, aga veri on ikka paksem kui vesi.

[Chat room: a speaker has complained that it is difficult to bring up one's own child and a foster child at the same time. Reply:]

'You try to be impartial, but blood is always thicker than water.'

Savisaar muidugi ütleb nü̈̈d, et Äripäev ei saagi muud teha, kui kiita Rootsi pankasid, sest kuulub ka ise rootslastele ning veri on ikka paksem kui vesi. (Äripäev weekly 3.02.10)

'Savisaar will of course say now that Äripäev cannot help but praise the Swedish banks because it [the newspaper] belongs to the Swedes as well, and blood is always thicker than water.' 
(18)

Hõõguvatele sütele oleks võinud ju tuha peale kraapida, kuid tuld see enam ei kustutanud. Väikeste eranditega mõistis seda kogu Eesti NSV juhtkond ja partei eestimeelne osa. Ja et veri on ikka paksem kui vesi, mõistsid eestlastest juhid üsna hästi, mis oma rahva seas ja inimeste südametes toimub. Õnneks oli Eesti juhtkond, erinevalt paljude teiste liiduvabariikide omast, lõplikult venestamata jäetud. (Õhtuleht newspaper) 'One could scrape some ash over the smouldering coal, but it would not put out the fire. With minor exceptions the entire leadership of the Estonian SSR and the pro-Estonian members of the party understood it. And because blood is always thicker than water, the Estonian leaders understood rather well what was taking place among their own people and in their hearts. Fortunately, the Estonian leadership, unlike many other republics, had not been completely Russianised.'

Other proverbs occurring both with and without the particle $i k k a$ are, for example, Hirmul on (ikka) suured silmad 'fear imagines many things' or Pill tuleb (ikka) pika ilu peale 'the joy won't last forever'. Usually they occur without $i k k a$ as a headline as in example (19) or as an introduction that places the following article into a wider context (20). However, ikka tends to occur in modern proverbs when it is a conclusion and is more closely associated with the previous text (sometimes as a clause as in (21)).

Hirmul on suured silmad? Mõnikord tõesti!

Hirm muudab seda, kuidas me maailma näeme, võimendades meie suutlikkust tuvastada häguste piirjoontega kujundeid, kuid pärssides samas peenemate üksikasjade tajumise võimet.

'Fear imagines many things? Sometimes, yes!

Fear changes the way we see the world; it enhances our ability to detect shapes with fuzzy contours while inhibiting the ability to perceive finer details.'

Istusime, ootasime aga midagi ei juhtunud. Mõne aja pärast keerasime magama ära ja oligi kõik. Hirmul on ikka suured silmad.

'We were sitting and waiting, but nothing happened. After some time we went to bed and that's it. Fear always imagines many things.' 
(21)

Aga las naerab, pill tuleb ikka pika ilu peale.

'But let him enjoy his laughs, the joy would never last forever.'

For comparison, we studied the proverb rääkimine hõbe, vaikimine kuld 'speech is silver, but silence is golden', which is also common, however, it never occurs with the particle $i k k a$. Rather, this utterance is used as a headline or with a special reference that it is a proverb. Thus, it is not integrated into the rest of the text in the same way as previously discussed examples (16-18 and 20-21). One might presume that $i k k a$ functions in proverbs both in the meaning 'always' and as a link with a more general discourse.

Nor does ikka occur in such proverbs that include some generalising component, e.g. igaüks 'everybody' in Igaüks on oma onne sepp 'every man is the architect of his own fortune'. Similarly, one cannot add $i k k a$ to a negative proverb, e.g. Veereva kivi alla sammal ei kasva 'a rolling stone gathers no moss'. Syntactically, it would be possible to add kunagi 'never'; however, its occurrence calls for further research.

Nevertheless, the meaning that emphasises the recurrence and typicality of the situation remains central in the word $i k k a$ and its variants. On the other hand, one can notice that $i k k a$ and $i k s$ are also used for formal purposes in order to achieve euphony.

Typically, ikka, ike, $i k s$, etc. occur in proverbs between the first and the second feet, for example, for the purpose of linking the same words, as in the pattern
(A) $\underline{\mathrm{X} i k k a \mathrm{X}}$ :
(8) veri iki veri
(10) laps on ikka laps

or for linking metrical feet with beginning rhyme, for example,

(B) $\underline{\mathrm{X} 1 \text { ikka X2: }} \quad$ (13) maias iks mao palutas (15) sulasel iki suur kõht

Sometimes the particle ikka may occur after the second metrical foot, linking the semantically coordinated halves; usually in such cases we can also observe some techniques of achieving euphony, for example, an equal number of metrical feet on both sides of the particle, as in

(C) X1Y1 ikka X2Y2: (14) Ema nisa iks latse suun. 'Mother's nipple is always in the child's mouth.' (cf. ema - latse, nisa - suu)

or

(D) X1Y ikka X2+and: (22) Hea jääb ikka heaks ja paha pahaks. 'The good will always remain good and the evil will remain evil.' 
Similar formal techniques, even breaking the boundaries of a compound, can also be found in South Estonian folk poetry, for example in the Setu epic Peko (Vabarna 1995). In South Estonian runic songs the $i k s$-form is used as a line extension, which is typically inserted after the first metrical foot. In this case $i k s$ is an expletive that can be inserted into a multi-foot word as well, e.g. imä$i k s-k o \tilde{n} \tilde{o}$ 'oh mother, always dear one'. The insertion is subject to certain phonological rules which are in principle in line with the insertion rules for English expletives suggested by Paul McCarthy (1982).

In South Estonian folk poetry the inserted $i k s$ often adds universality to the contrast, the meaning 'always taking place under normal circumstances', as in the previously analysed proverbs. The main function of $i k s$ as an expletive is to add prominence and to extend the metre, its motivation is poetic rather than semantic. Nevertheless, the poetic expansion is often accompanied by semantic prominence, which shows that the described situations and actions exceed the limiting temporal and situational conditions.

\section{CONCLUSION}

The article dealt with the adverb-particle $i k k a$ in various contexts and meanings. $i k k a$ is a polysemous word that realises its different meanings in different usage contexts. The original meaning of $i k k a$ is temporal; however, during the grammaticalisation process it has also acquired some non-temporal meanings.

The original meaning 'always, repeatedly, permanently' is also common in Estonian proverbs where it emphasises timeless validity of the presented information. The same meaning occurs also in contemporary spoken and written language but this usage context does not have the highest frequency.

The meanings 'yes, definitely (differently from what was thought)' and 'especially, very' are characteristic of contemporary informal conversations. This use of $i k k a$ plays an important role in making the conversation a coherent whole, both by highlighting several opinions concurrently (the temporary negative and the final affirmative ones) and its frequent occurrence as chains. One can witness the same in the use of proverbs as part of contemporary text-ikka serves as a means of linking a claim to discourse and general background knowledge.

One can see that in each text variety the use of $i k k a$ is motivated by different factors. Although each usage realises one or another lexical meaning ('always', 'still', 'sure', etc.), it is common that some additional motivation is involved. The latter could be sometimes phonological-metrical (in proverbs and in Setu folk songs), sometimes it makes the text a coherent whole by means of 
iteration (in informal speech and folk songs), and at other times it links an utterance to its cultural background (as in the use of proverbs in the contemporary media language). Domains of language usage that may seem remote on the surface could be actually closely interrelated, as it was shown in the article by the analysis of proverbs, runic songs, and informal conversation.

This article is based on the presentation delivered at the conference "From Language to Mind 3: On the Occasion of the 70th Birthday of Academician Arvo Krikmann" in the Estonian Literary Museum in 2009.

\section{NOTES}

1 Stephen Levinson claimed that sentences of the type $X$ is $X$ represent an implicature arising from intentional violation of Grice's cooperative principle (Levinson 1983: 110-111). Because the hearer knows that the speaker has some communicative function in mind when producing a speech act, even a formally meaningless utterance is regarded as a meaningful one, and for this reason the same lexeme is assigned different interpretations at the beginning and end of an utterance.

2 Proverbs in Estonian newspapers have been studied, for example, by Risto Järv (2009). He used Google as well, but searched for contexts where it was explicitly written that the sentence is a proverb or belongs to "folk wisdom". Our technique for searching is different: we chose some well-known proverbs and searched for them to find out usages with and without $i k k a$.

\section{REFERENCES}

EEW = Mägiste, Julius 2000. Estnisches etymologisches Wörterbuch, 2. Auflage. Helsinki: Finnisch-Ugrische Gesellschaft.

EKSS = Eesti keele seletav sõnaraamat I-VI. [Explanatory Dictionary of Estonian IVI.] 2009. Edited by M. Langemets \& M. Tiits \& T. Valdre \& L. Veskis \& Ü. Viks \& P. Voll. Tallinn: Eesti Keele Sihtasutus.

Erelt, Mati \& Kasik, Reet \& Metslang, Helle \& Rajandi, Henno \& Ross, Kristiina \& Saari, Henn \& Tael, Kaja \& Vare, Silvi 1993. Eesti keele grammatika II. Süntaks. [Grammar of the Estonian Language II. Syntax.] Edited by M. Erelt \& T. Erelt \& H. Saari \& Ü. Viks. Tallinn: Eesti Keele Instituut.

Heine, Bernd \& Kuteva, Tania 2002. World Lexicon of Grammaticalization. Cambridge: Cambridge University Press.

Järv, Risto 2009. Aren't Proverbs there for the Taking? References to Proverbs in Newspaper Texts. In: M. Kõiva (ed.) Media \& Folklore. Tartu: EKM Teaduskirjastus, pp. 239-268. 
Keevallik, Leelo 2009. Üldküsimuse lihtvastuste funktsioonid. [The Functions of Simple Answers to Estonian Yes-No Questions.] Keel ja Kirjandus, Vol. 1, pp. 3353.

Krikmann, Arvo 1997. Sissevaateid folkloori lühivormidesse I. Põhimõisteid, Žanrisuhteid, üldprobleeme. [Insights in the Short Forms of Folklore I. Main Concepts, Genrewise Relationships, General Problems.] Tartu: Tartu Ülikooli Kirjastus.

Levinson, Stephen C. 1983. Pragmatics. Cambridge: Cambridge University Press.

Lindström, Liina \& Lonn, Varje \& Mets, Mari \& Pajusalu, Karl \& Teras, Pire \& Veismann, Ann \& Velsker, Eva \& Viikberg, Jüri 2001. Eesti murrete korpus ja kolme murde sagedasema sõnavara võrdlus. [The Corpus of Estonian Dialects and the Comparison of the More Frequent Vocabulary of Three Dialects.] Keele kannul: pühendusteos Mati Erelti 60. sünnipäevaks. [Following the Language: Collection of Articles Dedicated to the 60th Birthday of Mati Erelt.] Publications of the Department of Estonian of the University of Tartu 17. Tartu: Tartu Ülikooli Kirjastus.

McCarthy, Paul 1982. Prosodic structure and expletive insertion. Language, Vol. 58, pp. $574-590$.

Vabarna, Anne 1995. Peko. Setu rahvuseepos - Setukaiseepos - The Setu Epic. Edited by P. Hagu \& S. Suhonen. Kuopio: Snellman-instituutti.

$\mathrm{SSA}=$ Suomen sanojen alkuperä. Etymologinen sanakirja 1. A-K 1992. Edited by E. Itkonen \& U.-M. Kulonen. Helsinki: Suomalaisen Kirjallisuuden Seura ja Kotimaisten Kielten Tutkimuskeskus. 